\title{
Molecular characterization of methicillin-resistant staphylococci among apparently healthy students
}

\author{
Helen Oroboghae Ogefere* and Lawrence Ayodele Ogunleye*,**
}

\section{ABSTRACT}

\section{BACKGROUND}

Staphylococcus aureus are widely considered a major factor of nosocomial and community-acquired infections. This work was aimed at determining the prevalence of methicillin-resistant $S$. aureus (MRSA) among apparently healthy students.

\section{METHODS}

A cross-sectional study was conducted involving 400 nasal swab samples randomly collected from students using sterile swab sticks and processed to recover $S$. aureus using standard microbiological techniques. Conventional methods were used to identify the isolates and antibiotic susceptibility tests were performed using Kirby-Bauer disc diffusion method according to performance standards of Clinical and Laboratory Standard Institute guidelines. Methicillin-resistance was detected phenotypically using cefoxitin $30 \mu \mathrm{g}$ discs. Bacterial deoxyribonucleic acid (DNA) extraction was done on cefoxitin-resistant staphylococci isolates only using ZymoResearch (ZR) fungal/bacterial DNA MiniPrep ${ }^{\mathrm{TM}}$ kit. A polymerase chain reaction assay targeting the $16 \mathrm{~S}$ rRNA, nuc, and mecA genes on $1.0 \%$ agarose gel electrophoresis stained with ethidium bromide was used to identify S.aureus and detect methicillin resistance.

\section{RESULTS}

The overall prevalence of MRSA was $5.8 \%$ using phenotypic methods. PCR amplification of the 23 phenotypically confirmed MRSA using $16 \mathrm{~S}$ rRNA and nuc genes identified staphylococci $23 / 23(100 \%)$ and S. aureus 23/23(100\%) at band size 886bp and 225bp respectively. However, 16(69.6\%) were positive for $m e c A$ gene at band size $532 \mathrm{bp}$ by PCR method. Poor level of susceptibility was recorded among the MRSA namely to erythromycin (26.6\%), cloxacillin $(0 \%)$, augmentin $(0 \%)$, cefuroxime $(0 \%)$, ceftriaxone $(0 \%)$ and ceftazidime $(0 \%)$. Ofloxacin was the most effective antibiotic $(60.9 \%)$.

\section{CONCLUSION}

Active antimicrobial surveillance of pathogenic staphylococci is important to analyze the infections and transmission rate for possible control measures.
*Department of Medical Laboratory Science, School of Basic Medical Sciences, College of Medical Sciences, University of Benin, Benin City, Nigeria **Medical Laboratory Unit, Cottage Hospital, Auchi Polytechnic, Auchi, Edo State, Nigeria.

\section{Correspondence:}

Helen Oroboghae Ogefere

Department of Medical Laboratory Science, School of Basic Medical Sciences, College of Medical Sciences, University of Benin, Benin City, Nigeria e-mail: helenogefere@yahoo.com phone number: +2348023509447

Date of first submission, September 17, 2018

Date of final revised submission, March 19,2019

Date of acceptance, March 20, 2019

This open access article is distributed under a Creative Commons AttributionNon Commercial-Share Alike 4.0 International License

Cite this article as: Ogefere $\mathrm{HO}$, Ogunleye LA. LMolecular characterization of methicillin-resistant staphylococci among apparently healthy students. Univ Med 2019;38:25-32. doi: 10.18051/UnivMed.2019.v38.25-32

Keywords: Methicillin-resistance, staphylococci, students, antibiotics, mесA, nuс. 


\section{INTRODUCTION}

The widespread resistance across various species of staphylococci has been reported in recent years. ${ }^{(1)}$ The most notable example is the emergence of methicillin-resistant Staphylococcus aureus (MRSA), which was reported just one year after the launch of methicillin in the early 1960s and has now become a major public health concern with its prevalence increasing globally. ${ }^{(2)}$ MRSA can cause the same types of infections as other $S$. aureus isolates such as: skin and soft tissue infections, including impetigo, folliculitis, furunculosis, abscesses, cellulitis, and wound infections. ${ }^{(2)}$ The MRSA has also been reported to cause invasive infections such as: pneumonia, endocarditis, osteomyelitis, septic arthritis, meningitis, septicemia, toxic shock and staphylococcal scalded skin syndromes in both infants and adults. ${ }^{(2)}$

The MRSA strains are resistant to nearly all beta-lactam antibiotics by producing an alternative penicillin-binding protein (PBP) known as PBP-2a. ${ }^{(3)}$ This protein is encoded by the mecA gene and has a low affinity to many beta-lactam antibiotics. MRSA strains are not only resistant to beta-lactams and cephalosporins, but also often show resistance to a wide range of antibiotics. ${ }^{(3)}$ The $m e c A$ is part of a mobile genetic element called staphylococcal cassette chromosome (SCCmec). The SCCmec is flanked by cassette chromosome recombinase genes ( $c c r A$ or $c c r B$ or $(c r C)$ that permit intra- and interspecies horizontal transmission of SCCmec. ${ }^{(3,4)} S$. aureus has four PBPs, (PBP1, PBP2, PBP3, and PBP4), with PBP2a/2' and PBP2 being responsible for peptidoglycan synthesis with transpeptidase and transglycosylase activities. ${ }^{(3)}$ In Nigeria, the prevalence of hospital associatedMRSA in clinical samples also varies from one region to another; $19.2 \%$ in Ekiti, $28.6 \%$ in Kano, $12.5 \%$ in Maiduguri and $38.0 \%$ in Benin. ${ }^{(5-9)}$ Several reports of studies on prevalence of community-associated MRSA (CA-MRSA) are also emerging in Nigeria; $10.8 \%$ in apparently healthy school children in Okada, Edo State, $41 \%$ and $56.7 \%$ in apparently healthy university students in Edo and Ogun states respectively, and $60.7 \%$ in otherwise healthy inhabitants of Uturu communities in Abia State. ${ }^{(10-12)}$

Characterization of the 16S rRNA gene is now well-established as a standard method for identifying and classifying species, genera and families of bacteria including staphylococci. ${ }^{(13)}$ The nuc gene, which encodes thermonuclease, is widely used as a specific target for the identification of $S$. aureus by polymerase chain reaction (PCR). ${ }^{(14)}$ Numerous in-house PCR based assays targeting the nuc gene alone or in combination with the mecA gene have been designed for fast screening or identification of methicillin-resistant $S$. aureus (MRSA) and methicillin-susceptible $S$. aureus (MSSA). ${ }^{(14)}$ In recent years, detection of $m e c A$ by PCR is also considered as the gold standard for identification of MRSA. ${ }^{(9,14)}$

Cefoxitin, being a cephamycin, is a stronger inducer of the mecA regulatory system than oxacillin. The cefoxitin disc test is easier to read than the oxacillin disc diffusion test and more accurate for detection of mecA mediated resistance. ${ }^{(15)}$ Many PCR based molecular methods were developed as alternative ways for accurate identification of MRSA. ${ }^{(16)}$ Most reports in our locality concentrate on phenotypic methods of identifying methicillin-resistant staphylococci especially among apparently healthy subjects and neglecting molecular characterization to identify the specific bacteria and genes responsible for antimicrobial resistance. This study therefore aimed to use the PCR assay to target three genes: a genusspecific 16S rRNA to detect staphylococcal DNA; nuc, which encodes the $S$. aureusspecific region of the thermonuclease gene and $m e c A$, a determinant of methicillin resistance among apparently healthy students of a tertiary institution in Auchi, Edo State, Nigeria. 


\section{METHODS}

\section{Research design}

This study was of cross-sectional design and was conducted using 400 apparently healthy students (consisting of 167 males and 233 females) of Auchi Polytechnic, Auchi, Edo State, Nigeria. Informed consent was obtained from all participants prior to specimen collection. Institutional ethical approval was obtained before study commencement. The duration of the study was from July 2016 to November 2017.

\section{Specimen collection and processing}

A total of 400 anterior nasal swab specimens were collected from the participants. All samples were collected from the left anterior nares using sterile swab stick soaked in sterile saline, labelled, packaged and transported immediately to the Microbiology laboratory for analysis. Staphylococcus aureus isolates were identified using API-Staph system (API System; bioMerieux, Paris, France).

\section{Antimicrobial susceptibility testing}

Antimicrobial susceptibility testing was carried out following the recommendation of the British Society for Antimicrobial Chemotherapy (BSAC) method. ${ }^{(17)}$ The test colonies were emulsified in sterile distilled water and the turbidity matched with $0.5 \mathrm{McF}$ arland. Once matched, a sterile cotton wool swab was dipped in the organism suspension and excess liquid was removed by turning the swab on side of the test tube. The entire surface of Mueller-Hinton agar plate was seeded by swabbing in three directions with the swab. The antibiotic discs were placed on the plate with the use of a sterile forceps. The antimicrobial agents tested were ofloxacin $(5 \mu \mathrm{g})$, amoxicillin-clavulanate $(30 \mu \mathrm{g})$, ceftazidime $(30 \mathrm{~g})$, erythromycin $(5 \mu \mathrm{g})$, cloxacillin $(5 \mu \mathrm{g})$, ceftriaxone $(30 \mu \mathrm{g})$, cefuroxime $(30 \mu \mathrm{g})$ and gentamicin $(10 \mu \mathrm{g})$. The plates were incubated at $37^{\circ} \mathrm{C}$ for $18-24$ hours.

\section{Detection of cefoxitin resistance}

All Staphylococcus aureus isolated were screened for methicillin-resistance by following CLSI guidelines using $30 \mu \mathrm{g}$ cefoxitin discs (Abtek U.K). ${ }^{(15)}$ Plates were read after incubation at $35^{\circ} \mathrm{C}$ for $18 \mathrm{~h}$. Zone diameter d" $21 \mathrm{~mm}$ was deemed to indicate cefoxitin resistance.

\section{Bacterial DNA extraction}

Bacterial DNA extraction was done on the 23 cefoxitin-resistant staphylococci isolates only. The DNA of the representative bacterial isolates was extracted using ZR fungal/bacterial DNA Mini Prep ${ }^{\mathrm{TM}}$ kit (Zymo Research Corporation, USA) following the manufacturer's instruction.

\section{PCR amplification of 16S rRNA, nuc and mec $A$ genes}

The 23 cefoxitin-resistant staphylococci eluted DNA extracts were amplified for $16 \mathrm{~S}$ rRNA, nuc and mecA genes by PCR using their respective primers as shown in Table 1. Briefly, a volume of $25 \mu 1 \mathrm{PCR}$ reaction mixture consisting of $12.5 \mu 1$ of PCR master mix, primers (1.25 $\mu 1$ each), double distilled water $(5 \mu \mathrm{l})$, and DNA template $(5 \mu 1)$ was used for PCR.

Table 1: List of primers amplified by PCR

\begin{tabular}{|c|c|c|c|}
\hline $\begin{array}{l}\text { Primer } \\
\text { Code }\end{array}$ & Oligonucleotide Sequence $\left(5^{6}-3^{6}\right)$ & $\begin{array}{l}\text { Annealing Temp } \\
\qquad\left({ }^{\circ} \mathrm{C}\right)\end{array}$ & $\begin{array}{c}\text { Expected } \\
\text { Amplicon Size } \\
\text { (bp) }\end{array}$ \\
\hline 16S rRNA & $\begin{array}{l}\text { 16S-1 (F) 5'GTGCCAGCAGCCGCGGTAA 3', } \\
\text { 16S-2 (R) 5'AGACCCGGGAACGTATTCAC 3' }\end{array}$ & 57 & 886 \\
\hline nuc & $\begin{array}{l}\text { (F) 5'TCAGCAAATGCATCACAAACAG3' } \\
\text { (R) 5'CGTAAATGCACTTGCTTCAGG 3' }\end{array}$ & 57 & 225 \\
\hline mecA & $\begin{array}{l}m e c A \text { F 5'AAAATCGATGGTAAAGGTTGGC 3' } \\
m e c A \text { R 5'AGTTCTGCAGTACCGGATTTGC 3' }\end{array}$ & 53 & 532 \\
\hline
\end{tabular}


Table 2. Prevalence rate of MRSA isolated from the nares of apparently healthy students using cefoxitin disc

\begin{tabular}{lcccccc}
\hline \multirow{2}{*}{ Gender } & \multicolumn{3}{c}{ S. aureus $(\mathbf{n}, \mathbf{\%})$} & \multicolumn{2}{c}{ Cefoxitin resistance (n,\%) } \\
\cline { 2 - 6 } & positive & negative & p value & positive & Negative & p value \\
\hline Gender & & & & & & \\
Male & $99(59.3)$ & $87(40.7)$ & 0.553 & $8(8.1)$ & $159(91.9)$ & 0.5219 \\
Female & $130(55.8)$ & $103(44.2)$ & & $15(11.5)$ & $218(87.5)$ & \\
\hline
\end{tabular}

Amplifications were performed using GeneAmp* PCR system 9700 thermocycler (Applied Biosystems, USA) beginning with an initial denaturation at $94^{\circ} \mathrm{C}$ for $3 \mathrm{~min}$ followed by 30 cycles of $30 \mathrm{~s}$ denaturation step at $94^{\circ} \mathrm{C}$, annealing at $57^{\circ} \mathrm{C}$ for $30 \mathrm{~s}$, extension at $72^{\circ} \mathrm{C}$ for $30 \mathrm{~s}$, and a final $7 \mathrm{~min}$ extension at $72^{\circ} \mathrm{C}$ followed by a hold at $4^{\circ} \mathrm{C}$. The $10 \mu 1$ of PCR products was electrophoresed on $1 \%$ Trisacetate-EDTA agarose gel stained with ethidium bromide for 60 min with $90 \mathrm{~V}$ current and viewed under UV trans illuminator (DolphinDOC plus, Wealtec Corporation). ${ }^{(18)}$

\section{Statistical analysis}

Statistical analysis was by the Chi $\left(\mathrm{X}^{2}\right)$ square test and Fischer's exact test where appropriate using INSTAT ${ }^{\circledR}$ software. A p value of $<0.05$ was deemed statistically significant.

\section{Ethical approval}

Ethical approval for this study was sought and obtained from Auchi Polytechnic Health Ethical Committee, Auchi with registration number: AP/HC.14/VOL.1/69.

\section{RESULTS}

Out of 400 apparently healthy students screened, 229 (57.3\%) were culture positive for S. aureus. Twenty-three $(7.7 \%)$ of these isolates were methicillin resistant using cefoxitin disc. This comprised $8(8.1 \%)$ males and $15(11.5 \%)$ females. Gender did not however significantly affect the distribution of MRSA $(\mathrm{p}=0.5219)$ (Table 2).

The prevalence of specific genes $16 \mathrm{~S}$ rRNA, nuc and mecA among cefoxitin-resistant S. aureus was $100 \%, 100 \%$, and $69.6 \%$

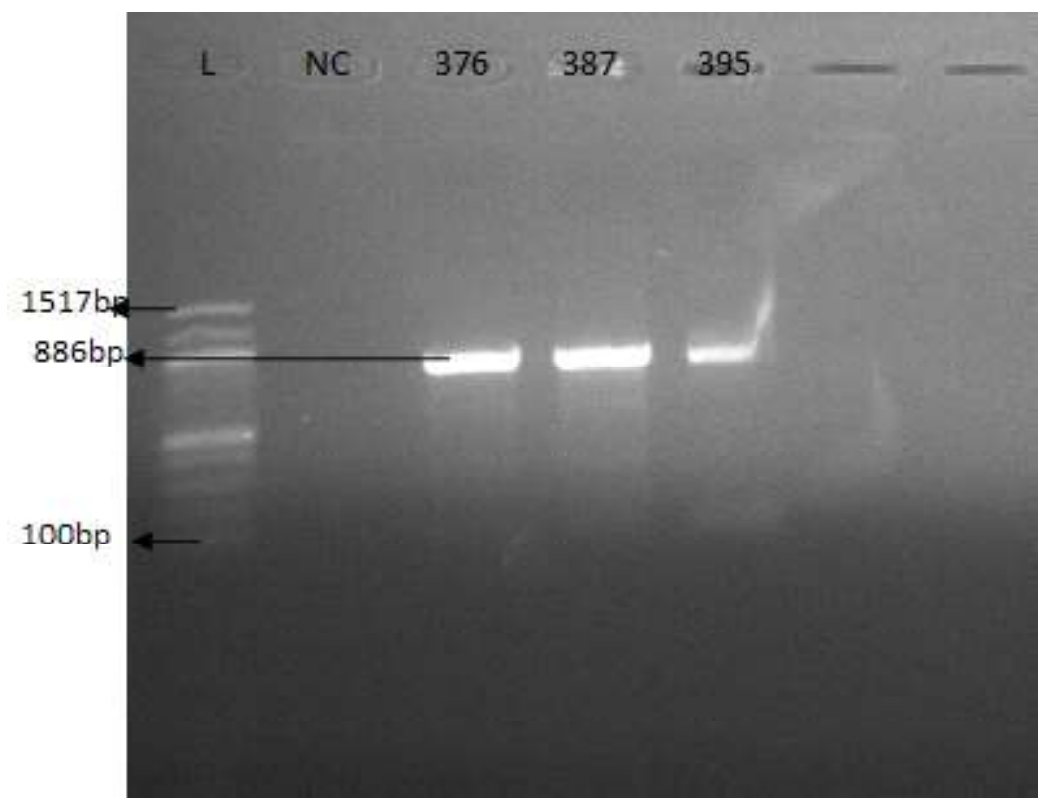

Figure 1. Polymerase chain reaction of $16 \mathrm{~S}$ rRNA gene in cefoxitin-resistant staphylococci isolates using $1.0 \%$ agarose gel electrophoresis stained with ethidium bromide to identify staphylococci. Left-hand lane is $100 \mathrm{bp}-$ $1517 b p$ DNA ladder (molecular marker) while NC is a no DNA template control 


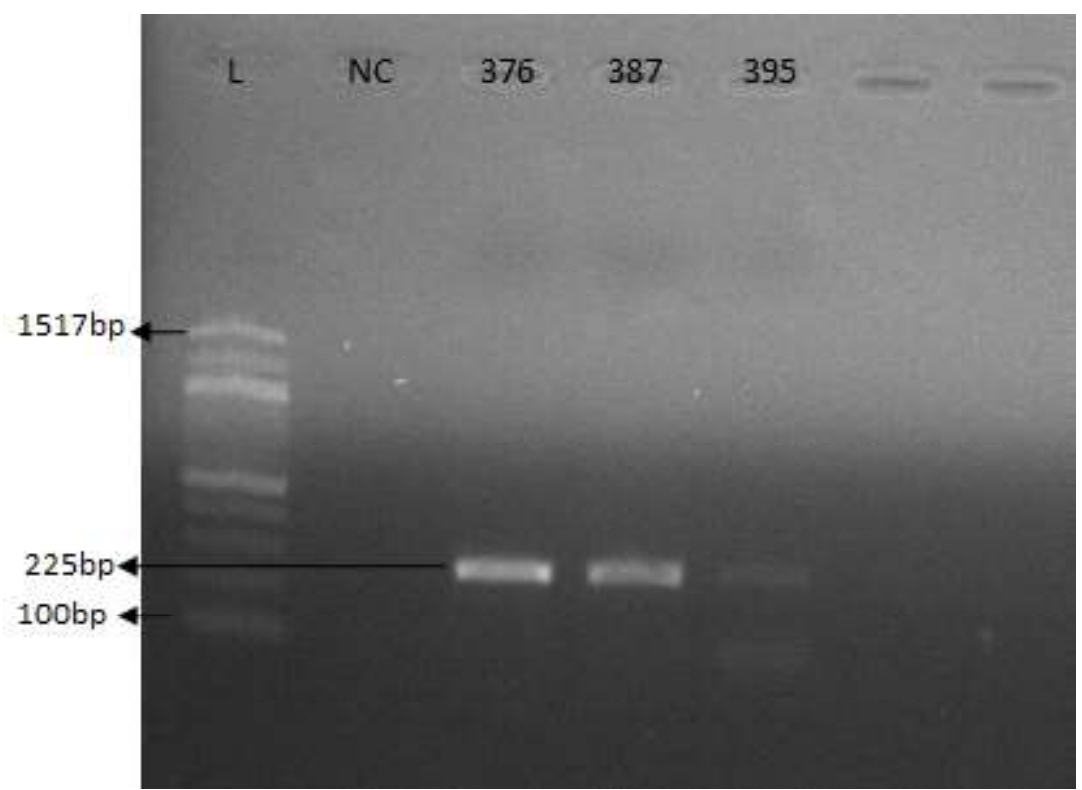

Figure 2. Polymerase chain reaction of nuc gene in cefoxitin-resistant staphylococci isolates using $1.0 \%$ agarose gel electrophoresis stained with ethidium bromide to identify Staphylococcus aureus. L is $100 \mathrm{bp}-$

$1517 \mathrm{bp}$ DNA ladder (molecular marker) while NC is a no DNA template control

respectively. Polymerase chain reaction results for detection of these genes can be seen in Figure 1,2 , and 3 respectively. Gender also did not significantly affect the distribution of $m e c A$ gene among cefoxitin-resistant $S$. aureus as 16 $(69.6 \%)$ isolates harbored the gene, in a maleto-female ratio of $6: 10(\mathrm{p}=0.975)$.

Methicillin resistant $S$. aureus showed poor susceptibility to commonly available antibiotics as $0 \%$ susceptibility was observed for ceftazidime, cefuroxime, ceftriaxone, cloxacillin and amoxicillin-clavulanate (augmentin). A poor level of susceptibility was recorded among the MRSA namely to erythromycin (26.6\%), The most active antibiotic was ofloxacin $(60.9 \%)$.

\section{DISCUSSION}

The prevalence rate of MRSA in this study was $5.8 \%$ (using cefoxitin disc). This finding is

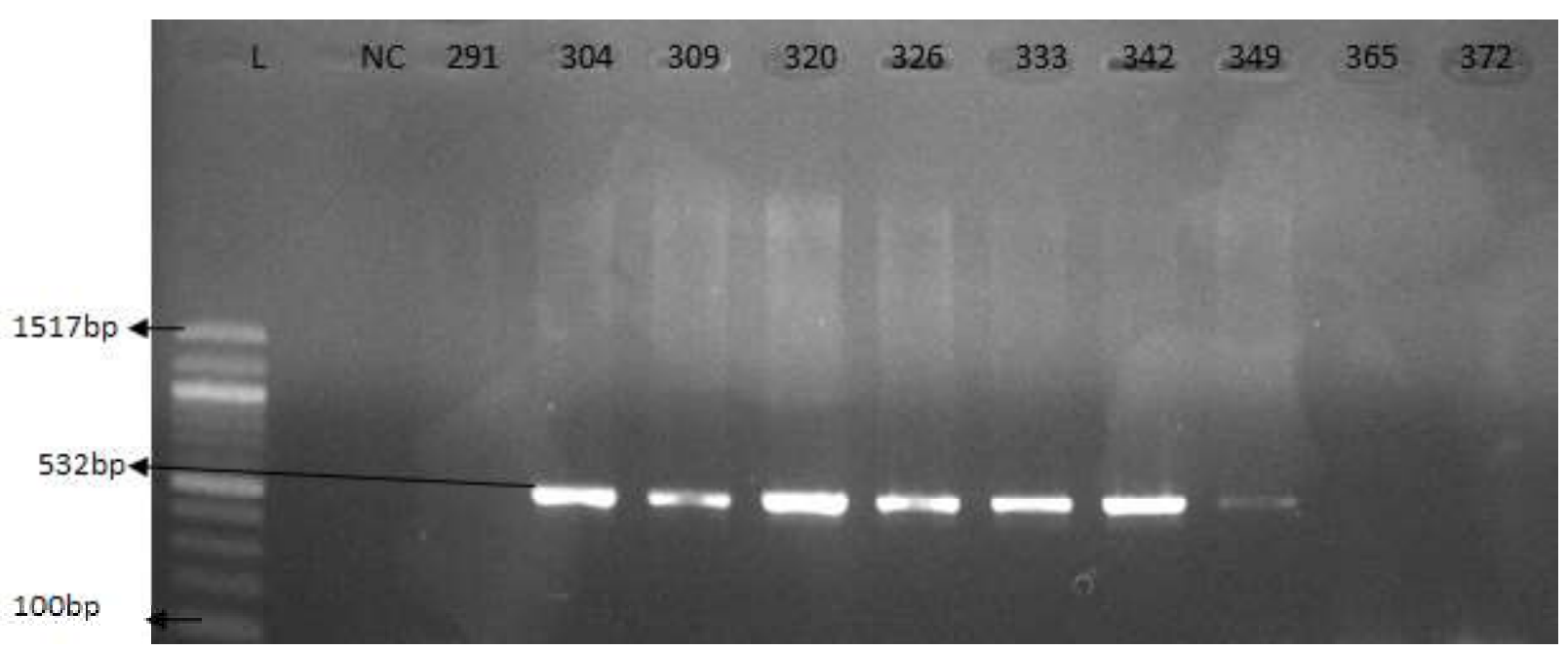

Figure 3.Polymerase chain reaction results for detection of $m e c \mathrm{~A}$ gene from confirmed cefoxitin-resistant Staphylococcus aureus isolates on 1.0\% agarose gel electrophoresis stained with ethidium bromide. $\mathrm{L}$ is $100 \mathrm{bp}-1517 \mathrm{bp}$ DNA ladder (molecular marker) while NC is a no DNA template control 
in agreement with the work of Mahde et al. ${ }^{(19)}$ which reported community-associated MRSA among healthy university students (4.2\%). Also, Okwu et al. ${ }^{(10)}$ reported a prevalence of $10.8 \%$ of community-associated MRSA in apparently healthy school children in Okada, Edo State, Nigeria. A study carried out in Colombia by Bettin et al. showed that the MRSA carriage status by medical students in their clinical rotations was 1.6\%. ${ }^{(20)}$ A study in Thailand reported 1\% prevalence among university students while Shadi recorded $6.7 \%$ MRSA colonization of nares among medical students in Jeddah, Saudi Arabia. ${ }^{(21,22)}$ On the contrary, Eke et al. ${ }^{(11)}$ reported $41 \%$ MRSA in apparently healthy university students in Ekpoma, Edo State, Nigeria. The difference in prevalence rates recorded could be attributed to method of identification of $S$. aureus isolates used to detect MRSA. Most other studies in Nigeria reported above used phenotypic identification as against the genotypic method used in this study. Ayeni and Odumosu had reported $85 \%$ misidentification rate of other microorganisms as Staphylococus aureus in Southern Nigeria when comparing phenotypic methods with genotypic (16S rRNA). ${ }^{(13)}$

Polymerase chain reaction (PCR) amplification of $16 \mathrm{~S}$ rRNA genes to identify staphylococci among the 23 MRSA of apparently healthy subjects was positive $(100 \%)$. This is in line with work of Degaim et al. ${ }^{(23)}$ where all isolates were positive for both 16S rRNA genes and $m e c A$ genes (100\%). Ayeni and Odumosu similarly showed the reliability of this genotypic test when compared with phenotypic tests in identification of $S$. aureus. ${ }^{(13)}$ This current study results agreed with Makgotlho, ${ }^{(24)}$ who showed that all isolates $97 / 97(100 \%)$ have 16S rRNA gene while mec $A$ gene was detected in 96/97 $(99 \%)$ of the MRSA isolates, the $1 / 97(1 \%)$ which did not show the presence of mecA gene was, however, phenotypically identified as MRSA.

In this study, the PCR amplification of nuc gene to detect Staphylococcus aureus among
MRSA showed $100 \%$ positive results. According to Vremera et al. ${ }^{(25)}$ the $n u c$ gene in S. aureus encodes the thermonuclease enzyme and amplification of $n u c$ gene is a potential method for rapid diagnosis of $S$. aureus infection. Therefore, the primer used in this study confirmed the ability of PCR as a fast and reliable method for detection of the $n u c$ gene to identify S. aureus strains. Also, of the 23 MRSA (using phenotypic method), 16 (69.6\%) were confirmed to be mecA positive by the PCR method. This is also similar to the work of Ibadin et al. ${ }^{(9)}$ where sensitivity and specificity of $m e c A$ gene in detection of MRSA was $89.5 \%$ and $90.3 \%$ respectively. Phenotypically methicillin-resistant strains without mecA gene and methicillin sensitive strains harboring $m e c A$ gene have been shown in previous studies. ${ }^{(13)}$ In this study, phenotypic and genotypic methods for detection of MRSA were used. The results of this study showed that $5.8 \%$ and $4.0 \%$ of $S$. aureus isolates were recognized as MRSA by cefoxitin disc diffusion test and PCR method respectively. Considering that detection of the mecA gene by PCR method is a gold standard method for identifying methicillin-resistance in $S$. aureus isolates, therefore the prevalence of MRSA in this study was $4.0 \%$.

In this study, a poor level of susceptibility was recorded among the MRSA namely to erythromycin $(26.6 \%)$, cloxacillin $(0 \%)$, augmentin $(0 \%)$, cefuroxime $(0 \%)$, ceftriaxone $(0 \%)$ and ceftazidime $(0 \%)$. This implies that MRSA isolates are generally resistant to betalactam antibiotics as previously reported. ${ }^{(9,10)}$ However, some MRSA isolates were susceptible to gentamicin (47\%) and ofloxacin $(60.9 \%)$. The sensitivity to the non-beta-lactam antibiotics was also similar to previous findings and it is recommended that non-beta-lactam antibiotics should be the preferred drugs for the treatment of community-acquired (CA) MRSA infections. ${ }^{(8,9)}$ The moderately high resistance $(52.2 \%)$ recorded for gentamicin was similar to the report on $S$. aureus from clinical samples $(44.4 \%) .{ }^{(9)}$ Ofloxacin (with sensitivity of $60.9 \%$ ) 
appeared to be the best antibiotic of choice for the treatment of MRSA infections in Auchi, Edo State and its surrounding communities.

A limitation of this study is hinged on the fact that only phenotypically identified MRSA strains were subjected to molecular analysis. More far reaching recommendations for routine microbiological practice may have been reached if all phenotypically identified $S$. aureus were screened for the $n u c$ gene. The study however holds important clinical implications as the role of carriers of MRSA is continually being explored in opportunistic infections and nosocomial outbreaks. Further studies that explore nasal carriage of hospital-acquired and community-acquired MRSA strains among apparently healthy subjects may deepen understanding of the superbug-MRSA in our region.

\section{CONCLUSIONS}

This present study established the phenotypic and genotypic prevalence rates of MRSA among apparently healthy subjects in the Auchi Polytechnic to be $5.8 \%$ and $4.0 \%$, respectively. It showed that the PCR technique is a very useful tool in detecting and identifying MRSA using 16S rRNA, nuc and mecA genes. In comparison with conventional methods, genotypic analysis of these three genes is still the gold standard for detecting MRSA. Ofloxacin was found to be most effective antibiotic against MRSA.

\section{CONFLICT OF INTEREST}

The authors declare no conflicts of interest

\section{ACKNOWLEDGEMENT}

The authors are grateful to all study participants for their cooperation and to the management of Auchi Polytechnic, Auchi, for the approval to carry out this research.

\section{CONTRIBUTORS}

HOO took part in the conception and design of the study. LAO took part in data generation. $\mathrm{HOO}$ and LAO contributed to data analysis and interpretation. Both authors participated in writing and approving the final draft of the manuscript.

\section{REFERENCES}

1. Peng Q, Hou B, Zhou S, et al. Staphylococcal cassette chromosome mec ( $\mathrm{SCCmec}$ ) analysis and antimicrobial susceptibility profiles of methicillinresistant Staphylococcus aureus (MRSA) isolates in a teaching hospital, Shontou, China. Afr J Microbiol 2010;4:844-8.

2. Rongpharpi SR, Hazarika NK, Kalita H. The prevalence of nasal carriage of Staphylococcus aureus among healthcare workers at a tertiary care hospital in Assam with special reference to MRSA. J Clin Diagn Res 2013;7:257-60. doi: 10.7860/JCDR/2013/4320.2741.

3. Garza-González E, Morfin-Otero R, Llaca-Diaz JM, et al. Staphylococcal cassette chromosome ( $\mathrm{SCCmec)}$ in methicillin-resistant coagulase negative staphylococci. A review and the experience in a tertiary-care setting. Epidemiol Infect 2010;138:645-54. DOI: https://doi.org/ 10.1017/S0950268809991361

4. Treesirichod A, Hantagoo S, Prommalikit O. Nasal carriage and antimicrobial susceptibility of Staphylococcus aureus among medical students at the HRH Princess Maha Chakri Sirindhorn Medical Center, Thailand: a follow-up study. J Infect Public Health 2014;7:205-9. doi: 10.1016/ j.jiph.2012.12.004.

5. Olowe OA, Kukoyi OO, Taiwo SS, et al. Phenotypic and molecular characteristics of methicillin-resistant Staphylococcus aureus isolates from Ekiti state, Nigeria. Infect Dr Resist 2013;6:87-92. DOI: http://dx.doi.org/10.2147/ IDR.S48809

6. Nwankwo BOK, Sale A, Magagi A, et al. Methicillin-resistant Staphylococcus aureus and their antibiotic susceptibility pattern in Kano, Nigeria. Afr J Clini Exper Microbiol 2010;11:1595689. DOI: http://dx.doi.org/10.4314/ajcem.v11i1. 44088.

7. Onemu OS, Ophori EA. Prevalence of multi-drug resistant Staphylococcus aureus in clinical specimens obtained from patients attending the 
university of Benin teaching hospital, Benin City, Nigeria. J Nat Sci Res 2013;5:154-9.

8. Shittu AO, Usman H, Adamu N, et al. Epidemiology and antibiotic susceptibility pattern of methicillin-resistant Staphylococcus aureus recovered from tertiary hospitals in North-eastern, Nigeria. J Med Medic Sci 2013;4:214-20.

9. Ibadin EE, Enabulele IO, Muinah F. Prevalence of $m e c A$ gene among staphylococci from clinical samples of a tertiary hospital in Benin City, Nigeria. Afr Health Sci 2017;17:100-10. DOI: https:// dx.doi.org/10.4314/ahs.v17i4.7.

10. Okwu M, Bamgbala S, Aborisade W. Prevalence of nasal carriage of community-associated methicillin resistant Staphylococcus aureus (CAMRSA) among healthy primary school children in Okada, Nigeria. J Natur Sci Res 2012;2:61-5.

11. Eke S, Abdulkadiri S, Okoro CJ, et al. The prevalence and resistivity pattern of Staphylococcus aureus isolates from apparently healthy university students in Ekpoma, Edo State, Nigeria. Inter J Bas Appl Innov Res 2012;1:183-7.

12. Ayepola, OO, Taiwo OS, Anifowose A, et al. Nasal carriage of Staphylococcus aureus and associated risk factors among students in a Nigerian University. Acta Sci Microbiol 2018;1:68. doi: 10.31080/ASMI.2018.01.0010.

13. Ayeni FA, Odumosu BT. False identification of other microorganisms as Staphylococcus aureus in Southern Nigeria. Trop J Pharm Res 2016;15: 1941-5. DOI: http://dx.doi.org/10.4314/tjpr.v15i9.19

14. Liu Y, Zhang J, Ji Y. PCR-based PCR-based approaches for the detection of clinical methicillinresistant Staphylococcus aureus. Open Microbiol J 2016;10:45-56. doi:10.2174/ 1874285801610010045.

15. Clinical and Laboratory Standards Institute. Performance standards for antimicrobial susceptibility testing approved standard M100S23. Clinical and Laboratory Standards Institute, Wayne, PA;2013.

16. Biswajit B, Shibendu B, Bappa M. Isolation of imipenem resistant Staphylococcus aureus from post-operation pus sample in oral and maxillofacial infections. Res J Pharm Bio Chem Sci 2012;3:896900 .
17. Andrews JM. BSAC standardized disc susceptibility testing method (version 8). J Antimicrob Chemother 2009;64:454-89.

18. Kaya EG, Karakoc E, Yagci S, et al. Evaluation of phenotypic and genotypic methods for detection of methicillin resistance in Staphylococcus aureus. Afr J Microbiol Res 2009;3:925-9.

19. Mahde SA, Reem QM, Nawfal RH. Nasal carriage rates of Staphylococcus aureus and CAmethicillin resistant Staphylococcus aureus among university students. J Microbiol Res 2015;5:123-7. doi:10.5923/j.microbiology.20150504. 01

20. Bettin A, Causil C, Reyes N. Molecular identification and antimicrobial susceptibility of Staphylococcus aureus nasal isolates from medical students in Cartagena, Colombia. Brazil J Infect Dis 2012;16:329-34. doi: 10.1016/j.bjid.2012. 06.017.

21. Kitti T, Boonyonying K, Sitthisak S. Prevalence of methicillin-resistance Staphylococcus aureus among university students in Thailand. Southeast Asian J Trop Med Pub Hea 2011;42: 1498-504.

22. Zakai SA. Prevalence of methicillin-resistant Staphylococcus aureus nasal colonization among medical students in Jeddah, Saudi Arabia. Saud Med J 2015;36:807-12. https://doi.org/10.15537/ smj.2015.7.11609.

23. Degaim ZD, Shani WS, Hamim SS. In Virulence factors of Methicillin Resistant Staphylococcus aureus (MRSA) isolated from burn patients. Inter J Curr Microbiol Appl Sci 2015;4:898-906.

24. Makgotlho PE, Kock MM, Hoosen A, et al. Molecular identification and genotyping of MRSA isolates. FEMS Immun Med Microbiol 2009;57:104-15.

25. Vremera T, Iancu LS, Logigan C, et al. Optimization of triplex real time PCR for detecting Staphylococcus aureus mecA, pvl and nuc genes. Roman Arch Microbiol Immun 2011;70:6973. 